\title{
How to combine the entry of young people in the labour market with the retention of older workers?
}

\author{
Werner Eichhorst ${ }^{1 *}$, Tito Boeri ${ }^{2}$, An De Coen ${ }^{3}$, Vincenzo Galasso ${ }^{2}$, Michael Kendzia ${ }^{1}$ and Nadia Steiber ${ }^{4}$
}

\footnotetext{
* Correspondence: eichhorst@iza.org 'IZA, Bonn, Germany

Full list of author information is available at the end of the article
}

\begin{abstract}
This paper provides an overview of the employment situation of young and old workers in the EU Member States, setting out the most recent development during the crisis and dealing with policies implemented to promote the employment of both groups. The evidence collected shows that there is no competition between young and older workers on the labour market. Structural or general policies to enhance the functioning of EU labour markets are crucial to improving the situation of both groups. However, the responsibility for employment policies still predominantly lies within Member States of the European Union, although initiatives taken at the EU level can provide added value, particularly through stimulating the exchange of experiences and facilitating regional and cross-border mobility throughout the EU.
\end{abstract}

\section{Introduction}

Promoting early retirement was a frequently used policy to keep open unemployment low in a phase of massive industrial restructuring in the 1970s and 1980s or even more recently in many EU Member States. In some countries, explicit policies to encourage older workers to leave the labour force were put in place to make jobs 'available' for young labour market entrants at the time. However, while such schemes were gradually dismantled in many European countries over the last two decades, we can observe a certain renaissance of the view that in a situation of crisis high levels of youth unemployment can be reduced when older workers retire more early. For example, on an experimental bases a "generation contract" is being implemented in Italy to encourage older workers to reduce their working time while young people should get better access to jobs. In September 2013, French President Francois Hollande expressed his view that high birth rates are responsible for high youth unemployment rates in France. Hence, it is important to study the issue if there is a real competition for jobs between the two age groups in EU Member States.

\section{The situation at first glance}

The recent economic crisis has had a huge impact on European labour markets, including both the young and old. Besides large cross-country variation, there has been a remarkable resilience of the employment rates of prime-aged and older workers compared to the more vulnerable situation of young people, who have been facing severe 
difficulties in finding jobs in many EU Member States. According to Eurostat data, the youth unemployment rate rose sharply in the EU-27, reaching an average of $23.0 \%$ in the second quarter of 2013 (as compared to around 15.6\% in 2008 and 22.8\% in 2012 [annual unemployment rates], see Table 1). Despite signs of economic recovery in some countries, the short-term prospects for youth unemployment remain bleak. Job creation is likely to lag behind economic recovery, with the result that the youth unemployment rate is likely to remain high over the coming years and the risk of experiencing longterm unemployment further increases. Already today, around a third of the young unemployed in the EU-27 have been jobless for more than a year. Youth have been harder hit by the economic crisis than older workers. Since 2008, the unemployment rate of youth (age 15-24) increased by 28.6 percentage points in Spain, by 33.2 percentage points in Greece and by 13.3 percentage points in Lithuania (also mentionable: Ireland (17.7), Cyprus (18.8) Portugal (21.3), Italy (14.0), Latvia (15.4), Bulgaria (15.4), Slovakia (15.0)), while that of older workers (age 55-64) increased by less than 10.6 percentage points in Spain and Greece (all other countries with a single-digit increase, except Germany and Malta with a single-digit decrease). It is important to note, however, that youth unemployment sky-rocketed in those countries where unemployment for older workers also increased more strongly than in other countries.

Yet again, it warrants mention that the countries where youth unemployment is particularly high (or where youth have been particularly hard hit by the economic crisis) are not those where older workers tend to work until comparatively high ages (or where older workers were least hit by the economic crisis). At country level, high activity rates for those aged 55-64 are not associated with high rates of youth unemployment (see Figures 1 and 2). In fact, in some countries such as Greece, low activity rates for older persons are combined with high youth unemployment, while in other countries such as Germany relatively high activity rates for older persons are combined with low youth unemployment. Moreover, positive changes in the activity rates of older persons between 2008 and 2012 are not associated with rising rates of youth unemployment. To the contrary, a weak negative relation is observed, suggesting that in countries successfully having increased the activity rates among those aged 55-64 despite recessionary pressures, youth unemployment has tended to increase less than in other countries (or has even fallen).

\section{Is there a competition between young and old workers?}

The theoretical foundation of the "lump of labour fallacy" rests on an almost perfect substitutability between young and elderly workers. According to this perspective, an old worker leaving the labour market makes room for a young worker who can perfectly substitute them in their previous task. However, several studies have questioned this notion of perfect substitutability between young and elderly workers on several grounds. Aubert et al. (2006) examined the effect of the introduction of new (IT) technologies and innovative workplace practices on the age structure of the workforce in French firms. These adjustments to new technologies and workplace practices may suggest the reasons and degree to which young and elderly workers are not perfect substitutes. Theoretically, unlike young workers, older workers - by being more skilled and experienced - may benefit potentially from technological and organisational innovations, which tend to be skill 
Table 1 Youth (un)employment rate vs. rate of elderly (un)employed workers in 2008 and 2012

\begin{tabular}{|c|c|c|c|c|c|c|c|c|c|c|c|c|}
\hline \multirow[b]{2}{*}{ GEO/TIME } & \multicolumn{3}{|c|}{ Youth unemployment rates (\%) } & \multicolumn{3}{|c|}{ Youth employment rates (\%) } & \multicolumn{3}{|c|}{ Elderly unemployment rates (\%) } & \multicolumn{3}{|c|}{ Elderly employment rates (\%) } \\
\hline & 2008 & 2012 & Difference & 2008 & 2012 & Difference & 2008 & 2012 & Difference & 2008 & 2012 & Difference \\
\hline European Union (EU-27) & 15.6 & 22.8 & 7.2 & 37.4 & 32.9 & -4.5 & 5.1 & 7.3 & 2.2 & 45.6 & 48.9 & 3.3 \\
\hline Belgium & 18.0 & 19.8 & 1.8 & 27.4 & 25.3 & -2.1 & 4.4 & 4.5 & 0.1 & 34.5 & 39.5 & 5.0 \\
\hline Bulgaria & 12.7 & 28.1 & 15.4 & 26.3 & 21.9 & -4.4 & 5.5 & 10.4 & 4.9 & 46.0 & 45.7 & -0.3 \\
\hline Czech Republic & 9.9 & 19.5 & 9.6 & 28.1 & 25.2 & -2.9 & 3.9 & 5.8 & 1.9 & 47.6 & 49.3 & 1.7 \\
\hline Denmark & 8.0 & 14.1 & 6.1 & 66.4 & 55.0 & -11.4 & 2.6 & 5.5 & 2.9 & 58.4 & 60.8 & 2.4 \\
\hline Germany & 10.6 & 8.1 & -2.5 & 46.6 & 46.6 & 0.0 & 8.5 & 5.9 & -2.6 & 53.7 & 61.5 & 7.8 \\
\hline Estonia & 12.0 & 20.9 & 8.9 & 36.4 & 33.0 & -3.4 & 4.1 & 7.0 & 2.9 & 62.4 & 60.6 & -1.8 \\
\hline Ireland & 12.7 & 30.4 & 17.7 & 45.9 & 28.2 & -17.7 & 3.3 & 10.5 & 7.2 & 53.7 & 49.3 & -4.4 \\
\hline Greece & 22.1 & 55.3 & 33.2 & 23.5 & 13.1 & -10.4 & 3.2 & 13.6 & 10.4 & 42.8 & 36.4 & -6.4 \\
\hline Spain & 24.6 & 53.2 & 28.6 & 36.0 & 18.2 & -17.8 & 7.3 & 17.9 & 10.6 & 45.6 & 43.9 & -1.7 \\
\hline France & 18.6 & 23.8 & 5.2 & 31.3 & 28.8 & -2.5 & 4.6 & 7.1 & 2.5 & 38.2 & 44.5 & 6.3 \\
\hline Italy & 21.3 & 35.3 & 14.0 & 24.4 & 18.6 & -5.8 & 3.1 & 5.3 & 2.2 & 34.4 & 40.4 & 6.0 \\
\hline Cyprus & 9.0 & 27.8 & 18.8 & 38.0 & 28.1 & -9.9 & 3.2 & 9.7 & 6.5 & 54.8 & 50.7 & -4.1 \\
\hline Latvia & 13.1 & 28.5 & 15.4 & 37.2 & 28.7 & -8.5 & 6.2 & 14.7 & 8.5 & 59.4 & 52.8 & -6.6 \\
\hline Lithuania & 13.4 & 26.7 & 13.3 & 26.7 & 21.5 & -5.2 & 4.4 & 11.9 & 7.5 & 53.1 & 51.7 & -1.4 \\
\hline Luxembourg & 17.9 & 18.8 & 0.9 & 23.8 & 21.7 & -2.1 & $:$ & 2.1 & $:$ & 34.1 & 41.0 & 6.9 \\
\hline Hungary & 19.9 & 28.1 & 8.2 & 20.0 & 18.6 & -1.4 & 5.0 & 7.9 & 2.9 & 31.4 & 36.9 & 5.5 \\
\hline Malta & 12.2 & 14.2 & 2.0 & 45.8 & 43.8 & -2.0 & 4.0 & 3.7 & -0.3 & 29.3 & 33.6 & 4.3 \\
\hline Netherlands & 5.3 & 9.5 & 4.2 & 69.3 & 63.3 & -6.0 & 3.2 & 4.7 & 1.5 & 53.0 & 58.6 & 5.6 \\
\hline Austria & 8.0 & 8.7 & 0.7 & 55.9 & 54.6 & -1.3 & 2.1 & 3.0 & 0.9 & 41.0 & 43.1 & 2.1 \\
\hline Poland & 17.3 & 26.5 & 9.2 & 27.3 & 24.7 & -2.6 & 5.3 & 7.4 & 2.1 & 31.6 & 38.7 & 7.1 \\
\hline Portugal & 16.4 & 37.7 & 21.3 & 34.7 & 23.6 & -11.1 & 6.6 & 12.8 & 6.2 & 50.8 & 46.5 & -4.3 \\
\hline Romania & 18.6 & 22.7 & 4.1 & 24.8 & 23.9 & -0.9 & 2.5 & 3.4 & 0.9 & 43.1 & 41.4 & -1.7 \\
\hline
\end{tabular}


Table 1 Youth (un)employment rate vs. rate of elderly (un)employed workers in 2008 and 2012 (Continued)

\begin{tabular}{|c|c|c|c|c|c|c|c|c|c|c|c|c|}
\hline Slovenia & 10.4 & 20.6 & 10.2 & 38.4 & 27.3 & -11.1 & 4.0 & 6.2 & 2.2 & 32.8 & 32.9 & 0.1 \\
\hline Slovakia & 19.0 & 34.0 & 15.0 & 26.2 & 20.1 & -6.1 & 6.4 & 11.2 & 4.8 & 39.2 & 43.1 & 3.9 \\
\hline Finland & 16.5 & 19.0 & 2.5 & 44.7 & 41.8 & -2.9 & 5.4 & 6.6 & 1.2 & 56.5 & 58.2 & 1.7 \\
\hline Sweden & 20.2 & 23.6 & 3.4 & 42.2 & 40.2 & -2.0 & 3.8 & 5.2 & 1.4 & 70.1 & 73.0 & 2.9 \\
\hline United Kingdom & 15.0 & 21.0 & 6.0 & 52.4 & 46.9 & -5.5 & 3.1 & 4.9 & 1.8 & 58.0 & 58.1 & 0.1 \\
\hline
\end{tabular}

Source: Eurostat, Ifsa_urgan \& Ifsa_ergan - Last updated November 18, 2013.

Notation: Not available. 


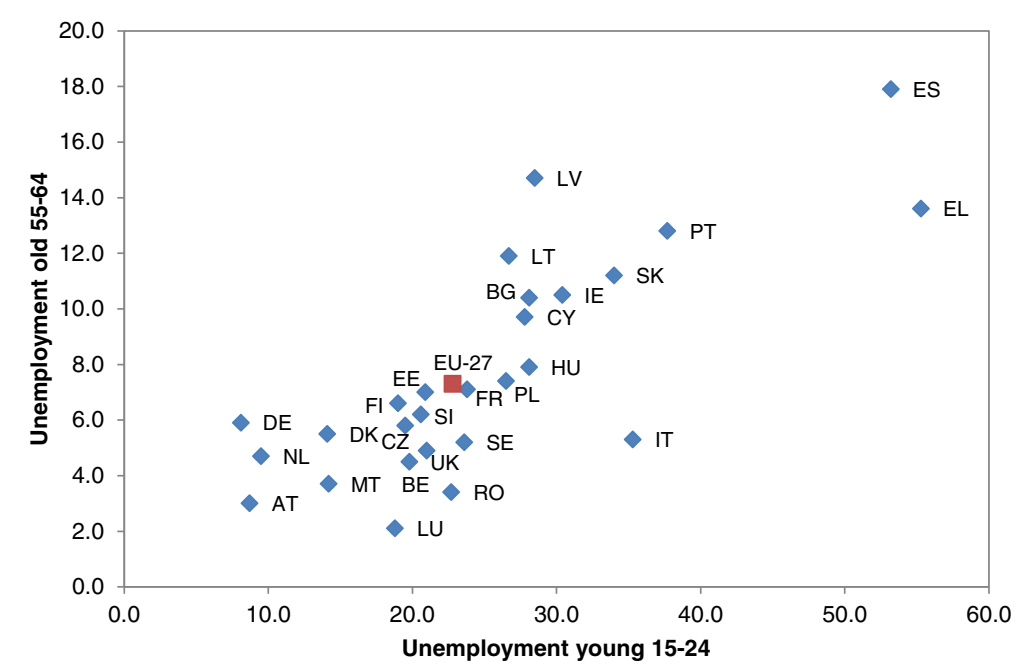

Figure 1 Unemployment rates of the two age groups, 2012. Source: Eurostat.

biased. On the other hand, innovation may hurt older workers by accelerating their skills obsolescence, with part of their competences becoming outdated (see Rosen 1975, and de Grip and van Loo 2002), and by requiring more adaptability and flexibility. Aubert et al. (2006) use firm-level data to find evidence of a lower wage-bill share for older workers in innovative firms, while the opposite holds for younger workers. This finding suggests a low degree of substitutability among workers of different ages, with new technologies increasing hiring opportunities significantly more for younger than for older workers. Moreover, this pattern also holds within occupational groups, thus suggesting lack of (or low) substitutability even among individuals of similar skills or educational levels. However, there is also some limited evidence on the substitutability at the firm-level. Studying the prolonged retirement age for women in Portugal in 1994 Portugal et al. 2009 did a quasiexperiment by comparing firms with and without women. They pointed out that an increase in retirement age decreases the hiring rate among the youths, particularly for women.

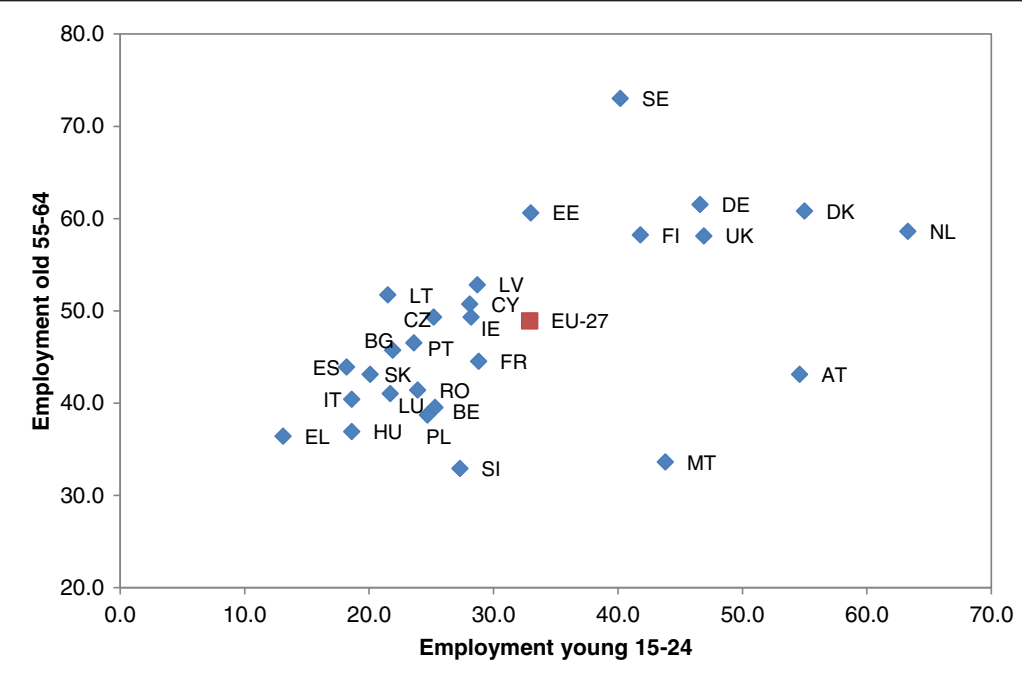

Figure 2 Employment rates of the two age groups, 2012. Source: Eurostat. 
Ageing may have different effects on the workers' productivity. Older workers may be more reliable and have better skills than average workers. However, older workers may have higher health care costs for firms and may be less flexible in accepting new tasks and even less appropriate for training (Barth et al. 1993). Establishing how age affects labour productivity is difficult, both because productivity is individual and sector specific, and because of the interaction between age, cohort, and selection effects. Nevertheless, age by itself is generally found to be a weak predictor of individual performance. While there exist wide differences between jobs and workers, older workers are typically regarded as more consistent, cautious, and slow but conscientious. Older workers have also fewer accidents and are less likely to quit, thus decreasing the hiring costs.

However, the productivity profile by age may also depend on the labour market institutions. For instance, several labour market institutions have been adjusted in the past to easy early departure from the labour force. Individual productivity is known to deteriorate if investments are not made to keep human capital updated. Hence, decreasing productivity for older workers may represent a self-fulfilling prophecy. In other words, a worker, who anticipates to retire early, will be less keen on investing in training to keep up his or her productivity level. Analogously, an employer, who expects a worker to retire early, will not have an incentive to invest in maintaining his or her productivity. If the current generations of older workers anticipated that they would have had the opportunity to retire early, they might have optimally decided to reduce their investment in human capital. In this case, the concave relationship between age and productivity would be due to the existence of mandatory retirement and not viceversa.

A conventional wisdom seems to hold among most employers - and perhaps even among many employees - that the average labour productivity drops at some point between 40 and 50 years old (see Johnson, 1993), although not many attempts have been made to test it empirically. And yet, there is typically more dispersion in labour performance within age groups rather than across age groups. An extended review of the existing research on age and productivity, mostly based on cross-sectional analysis and only few on longitudinal studies, by Warr (1998) shows no evidence that older workers perform worse than younger workers at their jobs. The research analysed included studies on job behaviours in combination with financial indicators to assess the outcome of using older workers, as well as lab experiments on the behaviour of workers of different ages.

Additional indications on the association between productivity and age emerge from observational data on employers or employees. Using US data on workers' individual characteristics, ability, jobs, and on-the-job performance, Avolio et al. (1990) for instance show that age is a worse predictor of work performance than length of job experience, particularly in highly complex jobs. Two studies that exploit matched employees-employer dataset to analyse the relationship between wages, productivity, and worker characteristics reach opposite results. Using U.S. data, Hellerstein et al. (1999) show that, over the life cycle, productivity and earnings rise at the same rate for prime-age and older workers. This result is in line with a theoretical framework, such as the general human capital model, which predicts wages to rise with productivity. Crepon et al. (2003) use instead French data to suggest that older workers are relatively overpaid. Moreover, while the wage profile by age is concave, the productivity profile by age stops rising and even decreases after some experience level. 
Still exploiting a matched employees-employer dataset, but on Finland, Ilmakunnas and Maliranta (2005) provide evidence that the wage productivity gap in increasing in age. They suggest this phenomenon to be driven by a substantial seniority bias in wage setting. In Dygalo and Abowd (2005), French matched worker-firm data are used to analyse experience/earnings and experience/productivity profiles. These empirical evidences show that earnings increase during employment spells, even if productivity declines. The authors suggest this pattern to be due to workers' preferences for increasing earnings profiles being matched by the firms. Still on French matched data, Aubert (2003), however, provides evidence of productivity being increasing and concave in age. This productivity growth slows down after age 40 and becomes almost zero - but not negative - after 50, in the manufacturing, construction and trade sector. In services, instead, there is only a slowdown after age 40 , but even beyond productivity continues to increase with age. Overall, older workers are not found to be less productive than younger ones. Finally, using Canadian matched worker-firm data, Dostie (2011) finds that both wage and productivity profiles are concave, with productivity dropping faster than wages for workers aged 55 and over.

Although a clear relationship between age and productivity is difficult to determine, employers may still have strong priors about the productivity of elderly workers. According to employers' opinions about aging issues in the Netherlands reported in Remery et al. (2003), employers are less favourable to elderly employees in firms with higher shares of older workers. In particular, hiring an older worker would not be considered an option even in case of staff shortage by about 40 percent of the employers. The substitutability between young and older workers is also reduced by the fact that non-employment for the older workers is a one-way street out of the labour force. Once they leave their long-term employer "to make room" for young workers, even highly productive workers will find it extremely hard to find alternative employment. In fact, long-term unemployment is much higher among older workers than among prime-age and young workers. Extending on-going employee-employer relationships is easier than to induce employers to hire older workers. However, older workers do face difficulties in retaining their jobs for two main reasons. First, they are perceived by their employers to be less able than younger workers to adapt to technological and organisational changes. Second, their wages may rise faster than their productivity. Bad health and difficult working conditions, such as long working hours, also play a role. As argued, if older workers lose their job, acquiring a new job becomes extremely difficult, and potential wage losses are large. In the OECD country, the hiring rate of the over 50 is on average less than half the hiring rate of prime-age workers (25-49). While this suggests some employers' reluctance to hire older workers, it may also be relate to weak search incentives and inadequate support from public employment services. The economic consequences of late-career job loss in the United States shown by Chan and Stevens $(1999,2001)$ are large and lasting negative effects on wages, assets, employment expectations, and actual employment. In particular, two years after a job loss occurred at age 55 only 60 percent of men and 55 percent of women were again employed, against an employment rates above 80 percent for non-displaced men and women who were working at age 55. Even four years after job loss, the gap in employment rates is still around 20 percent. This is in part because displaced workers are slow in finding a new job, and in part because exit rates from post-displacement jobs are higher than from other jobs. 
A widely observed phenomenon is that many firms employ older workers, but few firms hire older workers. Daniel and Heywood (2007) suggest two possible explanations: training and the productivity wage relationship. First, older workers have firm-specific skills, knowledge and experience, and thus they are important in training functions within firms. Second, when back-loading of the compensation profile is used to motivate greater lifetime effort, workers have to remain in the firm to cash in. Instead, older workers who are newly hired have little incentive to exert high effort, which makes them rather expensive. Moreover, firms using deferred compensation and internal labour markets will refrain from hiring older workers due to the steep wage tenure profile. Daniel and Heywood (2007) also show that modest financial incentives are not sufficient to modify the hiring practices particularly in firms that use back-loading and require specific human capital. Behaghel et al. (2004) find instead evidence that financial incentives do influence hiring behaviour of French firms: abolishing a firing tax for workers hired after the age of 50 increased the hiring of older workers.

In what follows we analyse whether there is substitutability between elderly and young workers in regional labour markets. In particular, we use EU Labour Force Survey data for 2009 to provide an additional empirical assessment of the degree of substitutability between elderly and young workers, analysing the correlation between the labour force exit rate of workers aged 55 to 64 years old and the unemployment rate for several groups of young individuals, aged from 21 to 30 years old. This analysis is conducted at a local labour market level for several EU countries ${ }^{1}$ including two nonEU countries ${ }^{2}$. The measure of the exit rate of the elderly workers and the unemployment rate of the young refers to the NUTS 2 unit - the basic region for the application of regional policy - as defined by Eurostat. The lump of labour would require a negative correlation between the exit rate of the elderly from the labour market and the youth unemployment rate. In fact, according to this view, by leaving the labour market, the elderly would make room for the young, with the youth unemployment rate consequently falling. Figure 3 Panel (a) suggests that no (statically significant) correlation indeed exists between the exit rate from the labour market of the elderly in 2009, measured in each NUTS 2 unit for all the EU countries and the youth unemployment rate, measured at the same regional level. In Boldrin et al. 1999 also used a crossnational approach between European countries and reached the same result.

Those results were confirmed by the recent OECD Employment Outlook (2013), where an instrumental variable estimator was used in a longitude cross country comparison to get rid of possible omitting variable bias. Instead of employment rates of older people life expectancy was used since it is assumed to be correlated with old people's employment rates but not with the employment rate of young people. They found no significant correlation between life expectation and the employment rate of young people. Moreover, Jousten et al. 2010, Salem et al. 2010 or Murphy and Welch 1992 also used longitude data within countries and emphasized weak substitutability between young and old workers.

If we examine the correlation between youth unemployment rate and exit rates from the labour market of the elderly by gender, an interesting result emerges. The overall exit rate of the elderly, which measures the proportion of male and female elderly workers leaving the labour market, is uncorrelated to the youth unemployment rate among the females (see Figure 3 Panel (d)). However, a positive correlation (statistically 


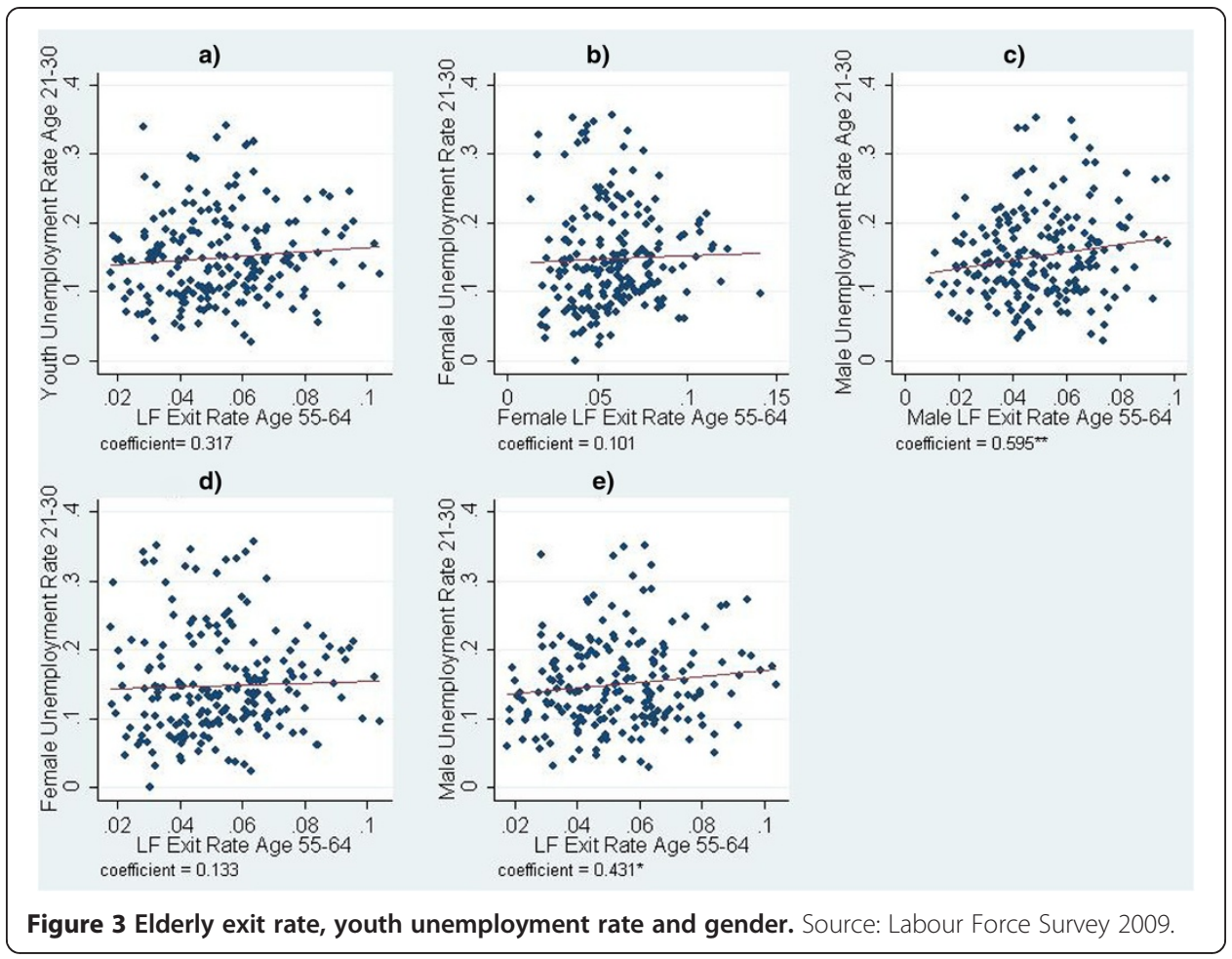

significant at the $10 \%$ level) emerges between the overall exit rate of the elderly and the male youth unemployment rate, as shown at Figure 3 Panel (e), with this finding overturning the lump of labour view.

In the local (regional) labour market, in which the elderly retire early - and thus exit the labour market - the unemployment rate of the young males is high, whereas lower level of youth unemployment rate for males are associated with low exit rates among the elderly. To further pursue the possibility of gender specific jobs, in which substitutability between young and elderly (male or female) workers occurs, we analyse the exit rate of the elderly and the unemployment rate of the young by gender. While no correlation emerges for females (see Figure 3 Panel (b)), a strong positive correlation becomes apparent between the elderly male exit rate and young males' unemployment rate, as displayed in Figure 3 Panel (c).

This finding, contradicting the lump of labour, supports the empirical evidence provided in other studies (see Gruber and Wise, 2010, and Van Dalen and Henkens, 2002). The explanation for this positive relationship proposed in this literature is that a large exit rate of the elderly workers, induced by early retirement, increases the cost of financing the pension system and consequently also the pension contribution (or labour tax) rate. The resulting increase in labour cost reduces the demand for workers, and thus also the employment rate, particularly among those individuals who are less attached to (and less protected in) the labour market, namely the young. From the literature there is virtually no evidence for the lump of labour hypothesis. However, when comparing different local labour markets in Italy, Messe et al. 2010 pointed out that a strong decrease in the exit rate among older workers reduces significantly the hiring rate of young workers. 
To further investigate the degree of substitutability between elderly and young workers, and thus to indirectly test the lump of labour, we use the $2009 \mathrm{EU}$ Labour Force Survey data to construct the correlation between the labour force exit rate of elderly workers and the youth unemployment rate at the NUTS 2 level by education group. We particularly consider highly (third level education), medium (upper secondary education) and low (lower secondary education) educated individuals for both the elderly exit rate and the youth unemployment rates. Interestingly, no correlation exists for high and medium educated individuals (see Figure 4). However, among low educated individuals, a strong positive correlation emerges between the elderly male exit rate and the young males' unemployment rate. Again, this finding not only contradicts the lump of labour, but it also rather suggests the existence of an opposite effect: early retirement (among the low educated elderly workers) worsening the labour market conditions of the low educated young workers. Overall, little evidence of a close substitutability between young and elderly workers emerges from the empirical results. On the contrary, evidence from regional labour markets tend to suggest that early exit of elderly workers from the labour market may indeed worsen the labour market outcomes of young individuals, as in the case of male and low educated workers.

\section{What is being done at the European and the national level?}

\subsection{Youth employment policies in place at the European level}

EU Member States are primarily in charge of paving the way for young people to enter the labour market. However, the EU can support them by exerting influence in political decision-making. In this context, the European Commission launched the "Youth on

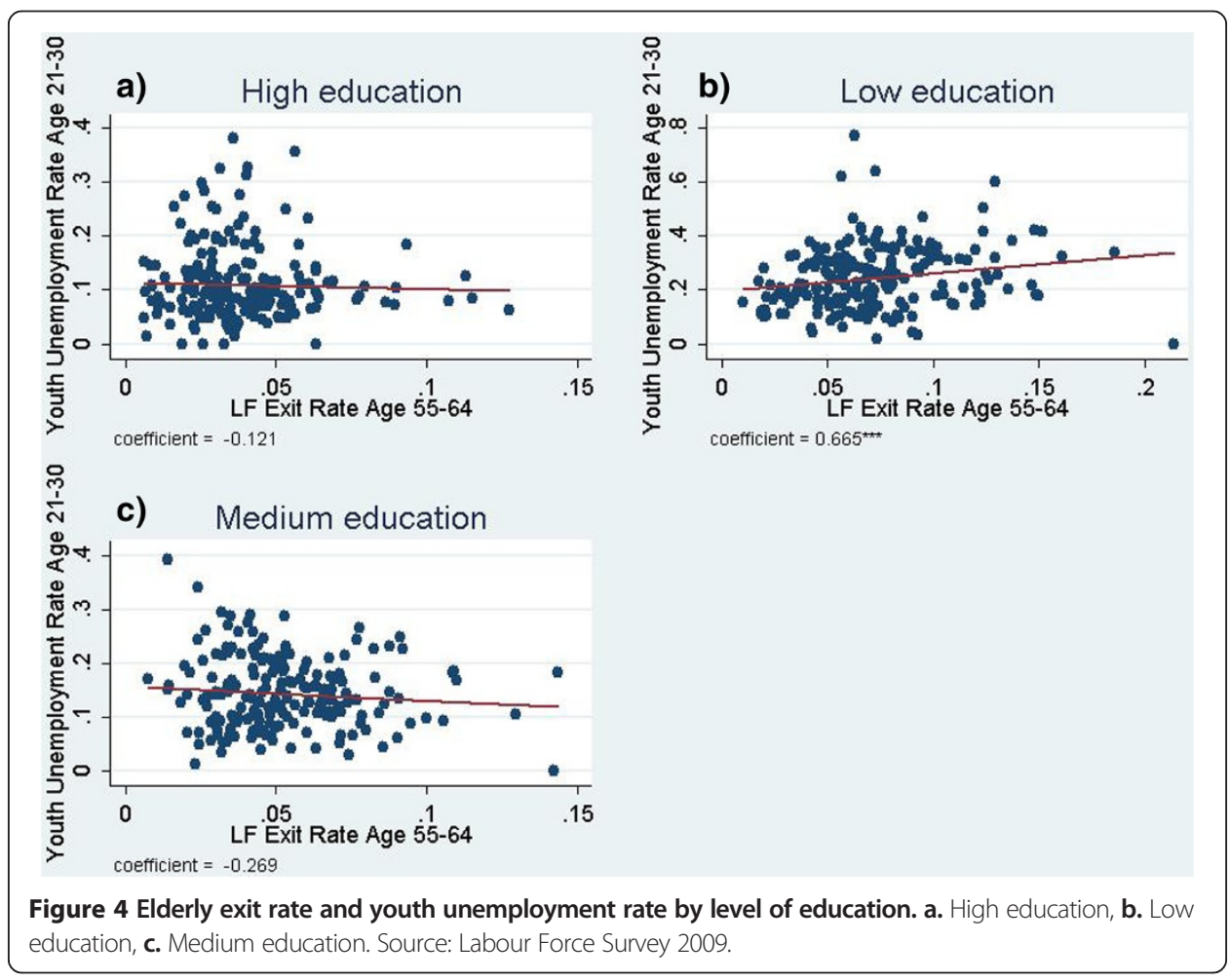


the Move" programme, an EU flagship initiative that began in 2010 as part of the "Europe 2020" strategy. The programme shall promote policy measures at national and European level to enhance educational and training systems (European Commission 2011b). In particular, "Youth on the move" focuses on three key areas. Firstly, the initiative addresses the development of modern education and training systems as being crucial to deliver key competences.

This contains the reduction of early school leaving to $10 \%$ by concentrating on prevention and targeting on those at risk of dropping-out of school the encouragement of vocational education and training (VET) and early workplace experience in the form of apprenticeship-type training and traineeships as well as the expansion of career and life-enhancing learning opportunities for non-formal and informal learning for the youth. Secondly, the initiative intends to promote higher education for the knowledge economy, supporting the development of transnational learning. To reach the goal of $40 \%$ attainment of higher education or equivalent, all Member States are supposed to modernise higher education. For example, this can be achieved by increasing the quality and transparency of its institutions and creating partnerships throughout the entire world. Thirdly, learning mobility to increase future employability is supported, also by promoting employment mobility across the European Union to ease young workers' moving and working within the European Union. This might provide young workers with experiences and skills, as well as contribute to better matching labour supply with labour demand. Accordingly, the procedures in terms of the social security system and the general free movement of workers shall be simplified (European Commission 2010).

In December 2011, the "Youth Opportunities Initiative" was launched as response to the growing youth unemployment since 2008, followed by the "employment package", adopted in April 2012. The package specifies policies regarding the reduction of early school leavers and a modernisation of education, and also addresses skills that should be developed to meet the demands of the labour market, thus easing the transition from school to work. In May 2012, in its resolution on the Youth Opportunities Initiative ${ }^{3}$, the European Parliament stressed the importance that Member States should take measures at national level to safeguard that young people are either employed, in education or training within a period of four months of becoming unemployed or leaving formal education (Council of the European Union 2013). Building upon existing Youth Guarantee approaches within some Member States, such as Austria, Finland, the Netherlands and Sweden, the establishment of a European-wide Youth Guarantee aims at supporting Member States with above average youth unemployment rates. This includes the establishment of partnerships and career guidance services at national, regional or local level to ensure that young people take informed decisions regarding their professional career and are aware of the fact that services are provided to them after leaving school. In addition to this, relevant labour market actors should create partnerships with employers to promote youth employment by offering first work experience and on-the-job-training. The Youth Guarantee shall also help safeguard an involvement of youth organisations or representatives to take into account the specific needs of beneficiaries (European Commission 2012a).

According to the European Commission's proposal, 'the term "Youth Guarantee" refers here to the fact that young people [aged 15-24] receive a good-quality offer of employment, continued education, an apprenticeship or a traineeship. An offer of continued 
education could also encompass quality training programmes leading to a recognised vocational qualification' (Council of the European Union 2013). Finally, at the EU's Council of Employment and Social Affairs Ministers on $28^{\text {th }}$ February 2013, the Council adopted the proposed Youth Guarantee Recommendation (European Commission 2013). In January 2011, the Commission approved "Tackling early school leaving: a key contribution to the Europe 2020 agenda". Thereafter, policies should particularly target children with immigration backgrounds. It also highlighted the importance of intervention schemes dealing with problems such as absenteeism and poor performances, as well as second-chance learning schemes.

In 2010 the Commission adopted a communication on "A new impetus for European cooperation in vocational education and training to support the Europe 2020 strategy". That is, vocational education and training shall endow young people with skills relevant to evolving labour markets. For instance, those skills encompass abilities related to the use of information technology. In September 2012, the European Commission submitted a proposal for a 'Council recommendation on the validation of non-formal and informal learning', as part of the 'Youth on the move' initiative. On the one hand, the proposal stresses the importance of creating new learning opportunities. On the other hand, it is designed to achieve a significant impact on the functioning of the labour market through a European-wide validation mechanism (European Commission 2012b).

\subsubsection{Policies in place at the national level}

The following section describes the policies introduced in the EU Member States to target young people's entry into the labour market during the last five years. First, policies regarding the general school education are taken into account, before considering training and employment-related policies as well as the role of activation policies related to amendments within the benefit systems.

4.1.1.1. School education/preventing early school leaving In the area of schooling, the most prominent means across the Member States relate to those preventing early school leaving. Early school leavers are those people aged 18-24 with a lower as secondary level education not participating in any further education or training. In countries such as Spain, Malta and Portugal, the rate of early school leavers exceeds 30\%. To guarantee that young people learn basic skills, several countries have installed extra support classes, observing pupils' achievements much closer than previously. For instance, in Greece, such kinds of classes exist throughout primary and secondary education in order to enhance pupils' performance. The 'Hope for suburbs' programme in France supports young people stemming from underprivileged areas, with 200 schools providing intense training for those delivering poor results. The 'Acting for youth' plan in the same country has extended compulsory education from 16 to 18 years, entailing the 'right to prepare for working life' in the sense of benefiting from training or taking up a job after leaving school. Other Member States have also introduced so-called secondchance schools, placing emphasis on practical skills and work experience or guidance measures for early school leavers. In Finland, early school leavers were assigned to personal advisors, providing advice and support in the form of a search team to find either employment or a way to further educate the early school leaver (European Commission 2011a). In the UK, the 2008 Education and Skills Act provides that all young people 
will have to remain in education or training until the age of 18 by 2015. Accordingly, young people have to either participate in education or training at a school, college and home education, or carry out work-based learning such as an apprenticeship (Skill 2009).

4.1.1.2. Development of training systems To better link the educational system with work experiences, a couple of Member States have initiated measures to close the gap between the educational system and the latter employment on the labour market. Several Member States have created vocational training programmes or expanded the number of vocational training places (European Commission 2011a). In Austria and Germany, a 'dual' vocational training system has long been in place, combining work experience through on-the-job learning and classroom education at a vocational school.

The system is supported by employers, trade unions and the government, particularly with regard to the legal framework and financial means. The system facilitates a relatively smooth transition from school to work (Biavaschi et al. 2012: 35). In Austria, the Vocational Training Act (Berufsausbildungsgesetz) entails an apprenticeship guarantee (Ausbildungsgarantie) for all young people up to the age of 18 (European Commission 2011a). The act was refined in 2008, providing a supra-company training programme until its completion for those who cannot find a company-based apprenticeship (Arbeiterkammer 2009). Accordingly, young people are trained until they have either found a company-based apprenticeship or completed the apprenticeship. In the meantime, the Public Employment Service Austria (Arbeitsmarktservice Österreich) supports those concerned by searching for a company-based apprenticeship (Hohbein and Wieland 2011). In Germany, the "National Pact to Promote Training and Young Skilled Workers in Germany" has been in place since 2004, introduced to offer training opportunities to young people willing and able to hold an apprenticeship. The Training Pact was refined in 2007, to include joint efforts of social partners (Federal Ministry of Labour and Social Affairs 2010).

4.1.1.3. Employment protection While high levels of employment protection decrease labour demand, employment protection cushions the negative effects of an economic slump on the labour market. On the other hand, low levels of employment protection lead to generally higher labour demand yet relatively high unemployment rates during an economic downturn. Young people are predominantly hired under low protection contracts (Boeri 2011). Nevertheless, the Spanish example shows that high employment losses can occur despite high employment protection (Balakrishnan and Berger 2009). The Spanish reform of the labour market carried out in 2010 and 2011 contained changes regarding individual dismissals. Today dismissals for economic reasons, triggered by current and expected losses or reductions in revenues, are considered a cause of fair dismissal. In this context, the advance notice was shortened from 30 to 15 days. Moreover, the Spanish government decided to create a new permanent contract including an express dismissal procedure with a maximum severance pay of 33 days' wages and no advance notice. For employees and workers with temporary contracts, severance pay was increased from 8 to 12 days' wages (Bentolila et al. 2012).

In Italy, uncertainty and costs related to dismissals were previously responsible for employers relying on temporary contracts (IMF 2012: 15-16). Therefore, the labour 
market reforms, approved by the Italian Parliament in June 2012, included individual dismissal rules and procedures. In order to reduce time and uncertainty related to individual dismissals, the discretionary area for judges in this respect was restricted. The "fast judicial track" intends to reduce indirect costs with regard to time and uncertainty owing to dismissal disputes (Fornero 2012). The previous legislation included the possibility of every employee working in a business unit with more than 15 employees, or for an employer with more than 60 employees to claim their job back. In addition, the employee was entitled to receive all lost salary since their dismissal and the employer could be forced to rehire the employees through the labour court's decision. Since the reform came into force in July 2012, the employee can no longer claim their job back in case of a lay-off due to an economic reason. Meanwhile the employee may only be granted an indemnity fixed by the labour court (Lexology 2012).

4.1.1.4. Active labour market policies (e.g. hiring subsidies) Lacking labour demand resulting from insufficient growth represents another factor for increasing unemployment among the youth, prompting active labour market measures aiming at increasing the employers' demand for hiring young workers (ILO 2010). Active labour market policies (ALMP) are usually understood as "bringing unemployed back to work by improving the functioning of the labour market in various ways. ALMP include programmes such as public employment services, labour market training and subsidised employment" (Boone and van Ours 2004: 2). One of the most prominent measures used to combat (youth) unemployment during the recession of 2008/2009 was short-time work resulting from an economic downturn and shortfall of orders. This scheme allows employers to reduce the working hours during times of economic difficulties. Many Member States have carried out short-time working schemes or partial unemployment benefit scheme during the economic slump, and some have even expanded the coverage of existing schemes or eased procedures for their application. (Hijzen and Venn 2011: 7). Across a number of Member States, there are no tailor made ALMPs for young people. However, several Member States have incentivised youth employment by hiring subsidies and reductions of the non-wage related costs. Such policies aim at stimulating additional demand from the employers' perspective, in order to create new jobs for the youth (European Commission 2011a). Measures such as wage and (labour market) training subsidies are taken to decrease work-related costs and incentivise the recruitment of young workers, and are typically provided by the government to support companies hiring or training an unemployed young employee or worker. Subsidies are sometimes paid directly to the employee or worker, with employment agencies or offices typically responsible for providing the funds. Public works programmes, which contain mostly direct employment opportunities through public activities, can also be mentioned in this context. Nonetheless, as stated by Kluve (2006), no significant positive effect and even some negative outcomes regarding the post-programme employment have been found (ILO 2010: 57-58). Another measure introduced with the outbreak of the financial crisis, is the promotion of self-employment. Other Member States have also initiated programmes to support self-employment, often encompassing mortgages or other forms of financial funding to start an own business and gain entrepreneurial knowledge (European Commission 2011a). 
4.1.1.5. Reforms of the benefit system due to activation policies Within the youth employment framework, the modernisation of the social benefit systems is addressed as part of the 'Youth on the move' initiative. Hereafter, access to social benefits should be safeguarded when perceived as appropriate. In addition, it should be expanded in the case of insufficient coverage of income safety for the youth. At the same time, activation measures and conditionality should guarantee that those concerned are actively searching for workplaces or willing to participate either in education or training. Young people often face the same requirements regarding the entitlement of unemployment benefits as older employees. Accordingly, if a young person does not meet the criteria for the entitlement owing to a lacking overall working period, they are unable to claim unemployment benefits (European Commission 2011a).

\subsection{Measures to prevent the early exit of the labour market of the older workers}

Measures fostering the employment of older workers should take two different aspects into consideration: first, the measures in countries with a high employment rate of older workers; and second, measures in countries with a strong dynamic in the employment rate of older workers. Within the second perspective, the decline in employment rate and rise in unemployment rate due to the economic crisis in 2008 hamper a clear picture of successful country specific measures. Therefore, we concentrate on the literature and empirical evidence largely prior to 2008. The development of the employment rates of older workers and the transition to retirement since 2008 can be seen indicative of how successful the national states were in managing the economic crisis.

\subsubsection{Reform of the social security incentive structures}

Pension reforms have been on the agenda in all Member States during the past decade (overview in European Commission 2008, box 2.1). First of all, early exit schemes were closed in the majority of countries, leading to increasing average age of exit from the labour market. In five countries ${ }^{4}$, the average exit age is still below 60 (in 2010), whereas twelve countries have a retirement age of 62 years or above ${ }^{5}$. An increase in the statutory retirement age causes different reactions among persons and firms, with the extent to which such a reform increases the employment rate depending on many factors. Hakola and Määttänen (2007) calculated the impact of the pension reform 2005 in Finland on the average labour market exit age. In the reform, there was a restriction in access to early retirement options and an increase in retirement age of two years (also an increase in pension accrual rate and actuarial adjustment factors), which led to an increase of the average labour market exit age by 8.5 months. The increase of the pension age for early exits in Austria by 2.2 years between 2000 and 2006 leads to a decrease in retirement of 25 percentage points among women of the relevant age cohorts and 19 percentage points among men. Employment increased by 10/7 percentage points among women/men, although the unemployment rate also significantly increased (+11/10 percentage points among women/men) (Staubli and Zweimüller 2011). However, for the outsiders, the unemployed older, the reform leads to a decrease in employment probabilities. Empirical findings for the Netherlands suggest that $11 \%$ of all people entering the disability pensions constitute a form of hidden unemployment (1994 - 2003) (Koenig and van Vuuren 2010). To stop this dynamic, new measures among employers and employees have been established. To reduce labour lay-offs, a 
firm's firing costs of older workers were increased through increased pension contributions in the case of lay-offs. The employer's contributions are experience rated. That is, the higher the amount of workers who exit from the labour market and enter disability pensions, the higher the employers contributions are. The introduced system of experience rating in the health and disability insurance reduced the inflows in disability (Hakola and Uusitalo 2005). In Germany, public pension reforms led to an increase of average labour exit age among women from 61.6 to 61.9 and among men 62.1 to 62.6 years within 2006 to 2009. The reason for this is the introduction of the meanstested 'unemployment benefit II' in combination with the shortened entitlement period that paved the way for a higher job-search intensity as well as the broader acceptance of fixed-term contracts and agency work. In France, the past reforms increased the employment rate of older workers and persons beyond the retirement age up to $13 \%$.

Unemployment benefit improves the job matches as employers and employees have a certain period to find the most suitable employee/job, and moreover macroeconomic efficiency can be enhanced. Employers can also use the insurance to reduce the labour costs in case of short term contraction of demand (hire-and-fire). Labour turnover varies among the Member States. To reduce short term labour turnover, many countries introduced a specific unemployment contribution rate for employers. If firms have a lay off beyond the average of the industry, the contribution rate to the unemployment insurance increases.

There is an indirect relationship between the employment level of older workers and health insurance. Health insurance can support employability of workers and workplace health promotion (WHP) through various incentives. For example, work organisation fosters an appropriate balance between individual level of skills, job demands and job control, work time, etc., and becomes particularly important with the increasing age of employees. Disability pensions and health insurance are closely related: A stricter health screening reduced disability pension in the US (Gruber and Kubik 1997). An experiment in the Netherlands shows that in regions with stricter screening, the disability rate declined (De Jong et al. 2011). Moreover, the compulsory rehabilitation plan has also had a positive impact on employment of older workers, reducing the disability inflow. Furthermore, Autor and Duggan (2003) calculated a significant screening effect on high-qualified employees but no effects on low qualified employees. In Sweden, there is just a small effect of stricter health screening on disability entrants and no effect on the employment level of older workers (Karlström et al. 2008). Johansson et al. (2012) find reduced entry rates between 1986 and 2008 in the context of screening stringency of the disability insurance in Sweden. The stricter health access criteria for disability pension in Austria decreased the disability entrances by ten percentage points, with $45 \%$ of the affected persons remaining employed, while $46 \%$ became unemployed and 9\% received sickness benefits through health insurance (Staubli 2011).

\subsubsection{Incentives of the tax system}

European tax systems in general and income and payroll tax systems in particular are not age-specific, given that the income tax rate relates to the level of income and not the age of the taxpayer. While there is extensive empirical literature on the relationship between taxes and the individual labour supply decisions ${ }^{6}$, there are few empirical findings of tax impacts on the labour supply decision of older workers. The age group that is in transition between employment and retirement is usually excluded from labour 
supply incentives. The labour income of workers includes decisions of qualification, income level of the industry, hours worked, age, gender, etc., with tax incentives corresponding to the elasticity of the mentioned components. Empirical findings show that working aged women are more responsive to taxes and wages than men. For US employees, Alpert and Powell (2012) find significant effects of payroll taxes on labour exit and pension entries of older workers (55 to 74 year old): the higher the tax burden of older men, the sooner they will quit employment for retirement. The authors suggest that a tax decrease for older workers by one percentage points would decrease labour market exits by $4 \%$. Age specific deductions of contributions in the social security systems try to reduce labour costs of older workers to promote their labour market attachment. In Finland, the employer pension contribution rate decreased by 1.2 percentages to $16.1 \%$, and vice versa increased the contribution rate for the older employee by 1.2 percentage points to $5.8 \%$ of pensionable income.

In Austria, there is also an evident reduction in social security contributions: for workers older than 60 years, firms do not pay contributions to the unemployment insurance ( $6 \%$ of pensionable income), to the work accidence insurance (1.4\%), insolvency safeguarding fund ("Insolvenzentgeltsicherung") (0.55\%), and contributions to the family-fund ("Familienlastenausgleichsfonds") (4.5\% of the assessment basis). Up to 2012, the social security contribution rate for employees older than 60 years decreased by 12.45 percentage points. There are no evaluations of the impact of the deduction on employment levels of older workers, and by 2013 the contribution deduction is going to be less generous.

\subsection{Measures promoting employment of both groups}

The specific problems of young and old workers within the labour market relate to the lack or obsolescence of relevant skills and insufficient work experience. To counter this, active labour market policies are in place in all EU Member States, along with labour market reforms to raise employment levels. In this context, it makes sense to distinguish between targeted and universal policies, with targeted policies addressing specific socio-economic groups such as youths and older workers and universal policies aiming to generally stimulate employment growth and job creation, thereby benefiting a broad range of potential target groups.

\subsubsection{Targeted measures}

The evidence collected shows that there are very few targeted schemes trying to simultaneously promote the employment of young and old workers. Most targeted measures focus on training and hiring incentives to employers, such as specific skill adjustment programmes or hiring incentives. Nonetheless, diverse measures may be used to reach the same goal: while some of these measures were designed to encourage the retention of older workers, others focus on improving the labour market access and early career mobility of young people. One such measure involves the introduction or expansion of tax and social security incentives for employers and/or employees to hire and retain younger and older workers (Eurofound 2012). Similar financial incentives targeting both younger and older workers at risk can be found in other countries. Specific programmes aiming to establish a labour market "bridge" between older and younger workers rarely exist. However, one particularly notable policy approach in this respect 
is old-age part-time work. In some countries, this was designed to promote a gradual exit from work to retirement, thereby prolonging the employment career whilst also facilitating the integration of younger people into work.

In an ideal-type, old-age part-time work programme employers received a subsidy if they: (a) established a phase-out programme for older workers and topped up their pension contributions during the part-time work period; and (b) hired a young unemployed person as a replacement worker. One prominent example is the system that was place in Germany until 2009 (Altersteilzeit). However, old-age part-time work neither helped to retain older workers, as it was hardly used for progressive retirement but rather for premature exit from work, nor was there any positive effect on the employment of younger workers (see the evaluation study by Wanger 2009). Indeed, at best it was neutral regarding its effects on younger workers while effectively lowering the employment rate of older workers. This is also confirmed by the similar case of Austria (Graf et al. 2011). Furthermore, the costs for subsidised early retirement had to be borne by employers and employees via social security contributions. In turn, this might have actually reduced overall demand for labour, therefore with detrimental effects on younger people. Accordingly, removing older workers from the labour market can harm the employment prospects of younger people.

\subsubsection{Universal measures}

More universal policy approaches are fundamentally different as they aim at more jobs and better labour market access for all working-age people. Such general policies to promote high employment and facilitate mobility on the labour market for all groups are beneficial for all (Bassanini and Duval 2006), and thus are also conducive to the better employment record of young and old workers. The most fundamental policy areas and initiatives in this area include:

- skill formation and updating via vocational education and training and continuous vocational training later in life;

- effective forms of active labour market policies and activation strategies that make the receipt of social benefits for working-age people conditional upon reintegration efforts;

- policies to reduce taxes on work and non-wage labour costs, particularly involving expenditure for 'passive' social benefits granted to working-age people without a reintegration perspective;

- reforming employment protection to enable entry into the labour market and facilitate mobility between jobs; while the effects of reforms of employment protection legislation may generally be ambiguous, deregulatory reform on the labour market to promote (re)entry into employment by creating flexible jobs can at least facilitate labour market access for those outside the labour market, to some extent.

These general employment-friendly policies can have particularly beneficial effects on demographic groups seeking access to the labour market at a young age or when reentering the labour market after a phase of unemployment or inactivity. Therefore, it can be stated that universal policies can have a particular impact on certain groups. Regarding active labour market policies, one can argue in a more generalised fashion that 
many active labour market policy schemes can be targeted flexibly to address the employment obstacles of target groups identifiable in the national context, with age representing just one parameter among others here. In particular, ALMPs can help to make jobseekers more attractive to potential employers by reducing labour costs in the initial phase of employment or by raising productivity via skills upgrading.

In principle, active labour market policies such as (i) publicly sponsored training, (ii) hiring incentives for employers, (iii) start-up support, (iv) in-work benefits topping up low wages and (v) activation policies establishing an effective conditionality between benefit receipt and participation in ALMP programmes or acceptance of job offers are available to address the whole working-age population. As shown above, there is some potential to deliver effective active labour market policies tailored to the needs and employment barriers of particular groups, such as the young and the old, so that the employment prospects of both groups are promoted. To summarise, general policies are particularly relevant in terms of raising the employment levels of all, including young and old workers. Targeted policies are justified if particular barriers to employment exist, yet age is only one criteria amongst many in identifying specific target groups and designing policies accordingly. As can be seen from the experiences of EU Member States, it is less obvious to have policies addressing specifically young and old workers (but only them). Rather, if these groups are targeted, they are dealt with separately. Finally, consistently both with respect to developments over time and in cross-country comparisons, there is no competition between the two groups in terms of opportunities to obtain jobs. Accordingly, there is also no economic or political trade-off between a good start into employment for young workers and the retention of older workers.

\section{Conclusion and policy recommendations}

This paper provides an overview of the employment situation of young and old workers in EU Member States. Regarding the recent and present situation of young and old workers in European labour markets, it is evident that young people have suffered most from the recent crisis in terms of rising unemployment and declining employment, particularly in countries where entry into employment and particularly into permanent jobs, was even difficult before the crisis. At the same time, the employment rates of older workers have been more resilient and less responsive to the crisis, owing to the withdrawal of early retirement incentives and a more stable employment position compared to younger labour market entrants. With respect to policies being implemented to further the labour market participation of young and old workers, it should be noted that particular barriers might exist for young and old workers. Policies such as hiring subsidies, extended training programmes, start-up support schemes and general activation programmes have been put into practice to combat the unemployment of working-age people, including younger and older workers. Regarding the former, many EU Member States have developed a set of targeted active labour market policies and flexibilised the labour market. However, not all such programmes are delivered in an effective way, and some preparatory or temporary training and employment schemes may simply postpone integration problems, as is the case for fixed-term contracts and other flexible forms of employment that often fail to provide a proper stepping-stone into more stable employment. Concerning older workers, the withdrawal of early 
retirement programmes, less generous unemployment benefits and changes in public pension schemes have contributed the most to prolonging the working life. Moreover, training over the life cycle and other active labour market policies can also have a positive impact in this regard. Higher employment rates of older workers often means a longer employment of employed people, whereas re-entry into work may still be difficult for the older unemployed. It is most notable that incentives to retire early or move into long-term unemployment benefit have been cut, with EU Member States having generally not opted to further expand early retirement in the current situation, unlike in early economic crises.

Comparing the two groups, more significant problems are found regarding youth unemployment and their entry into the labour market in countries where the labour market is deeply segmented, where effective vocational education and training systems are lacking and the economy is in a particularly difficult situation due to the crisis. The evidence shown here also highlights that structural, general policies are most relevant in promoting the employment of both younger and older workers, and are more prominent than targeted policies addressing either group. In fact, while targeted policies focus on either group, policies aiming to establish employment 'bridges' between young and older workers have not been of major importance, and where implemented, have proven to be rather ineffective. Most importantly, it can be clearly noted that the early retirement of older workers is neither beneficial nor necessary to promote young people's entry into the labour market. Indeed, a labour market arrangement that is sufficiently flexible and adaptable through well-designed vocational education and training, as well as continuous training policies, activation and active labour market policies, wage setting and labour market regulation and tax and benefit systems by setting the right incentives is the most conducive approach to achieving a high level of employment. There is also strong evidence that there is no fixed amount of labour that has to be distributed among different age groups; moreover, despite a widespread belief in a 'lump of labour', this does not hold empirically.

Apart from particular circumstances that may arise in certain (stagnant) firms or sectors with no labour mobility, there is no competition for jobs between young and old workers, given that there is only limited substitutability of the two age groups, owing to differences in sectors, occupations, experiences and skills. There is no need for concern regarding negative side effects of the better employment retention of older workers. Rather, this is generally beneficial for overall labour market performance in easing the burden of ageing on the welfare state in order for young people to also benefit from the higher employment of older workers.

\section{Endnotes}

${ }^{1}$ Austria, Belgium, Cyprus, Czech Republic, Denmark, Estonia, Finland, France, Germany, Greece, Hungary, Ireland, Italy, Lithuania, Luxembourg, Latvia, Poland, Portugal, Romania, Slovakia, Slovenia, Spain, Sweden, and the UK.

${ }^{2}$ Israel and Norway.

${ }^{3}$ European Parliament resolution on the Youth Opportunities Initiative (2012/2617 (RSP)), 24.5.2012.

${ }^{4}$ Lithuania, Hungary, Poland, Slovenia, Slovakia. 


\author{
${ }^{5}$ Denmark, Germany, Estonia, Ireland, Spain, Cyprus, Latvia, Netherlands, Portugal, \\ Romania, Sweden, UK. \\ ${ }^{6}$ E.g., Auten et al. 2008; Saez et al. 2012.
}

\title{
Competing interests
}

The IZA Journal of European Labor Studies is committed to the IZA Guiding Principles of Research Integrity. The authors declare that they have observed these principles.

\section{Acknowledgement}

This paper is based on a joint report presented to the European Parliament in 2013 (Eichhorst et al. 2013, available online as IZA Research Report 53).

Responsible editor: Martin Kahanec

\section{Author details}

${ }^{1}$ IZA, Bonn, Germany. ${ }^{2}$ Bocconi University, Milano, Italy. ${ }^{3}$ IDEA Consult, Brussels, Belgium. ${ }^{4}$ WIFO, Vienna, Austria.

\section{Received: 17 December 2013 Accepted: 24 June 2014}

Published: 06 Oct 2014

\section{References}

Alpert A, Powell D (2012) Tax Elasticity of Labor Earnings for Older Individuals. Michigan Retirement Research Center Research Paper No WP 2012-272. doi:10.2139/ssrn.2188401

Arbeiterkammer (2009) Berufsausbildungsgesetz (BAG). AKTUELL, Das Info-Service der AK 8, Wien

Aubert P (2003) Productivity, Wage and Demand for Elder Workers: An Examination of French Matched EmployerEmployee Data, Technical Report. INSEE, Paris

Aubert P, Caroli E, Roger M (2006) New technologies, organisation and age: firm-level evidence. Econ J 116:F73-F93. doi:10.1111/j.1468-0297.2006.01065.x

Auten G, Carroll R, Gee G (2008) The 2001 and 2003 tax rebate reductions: An overview and estimate of the taxable income response. Natl Tax J 61:345-364

Autor DH, Duggan MG (2003) The rise in disability recipiency and the decline in unemployment. Q J Econ 118:157-205. doi:10.1162/00335530360535171

Avolio BJ, Waldman DA, McDaniel MA (1990) Age and work performance in nonmanagerial jobs: The effects of experience and occupational type. Acad Manage J 33:407-422. doi:10.2307/256331

Balakrishnan R, Berger H (2009) Regional Economic Outlook: Comparing Recessions in Germany, Spain, and United Kingdom, IMF Survey Magazine. http://www.imf.org/external/pubs/ft/survey/so/2009/num111809a.htm. Accessed 27 November 2013

Barth MC, McNaught W, Rizzi P (1993) Corporations and the Aging Workforce. In: Mirvis PH (ed) Building the Competitive Work-Force: Investing in Human Capital for Corporate Success. Wiley, New York, pp 156-200

Bassanini A, Duval R (2006) Employment Patterns in OECD Countries: Reassessing the Role of Policies and Institutions. OECD Social, Employment and Migration Working Paper No 35. OECD, Paris

Behaghel L, Crépon B, Sédillot B (2004) Contribution Delalande et transitions sur le marché du travail. Économie et Statistique 372:61-88. doi:10.3406/estat.2004.7267

Bentolila S, Dolado JJ, Jimeno JF (2012) Reforming an insider-outsider labor market: the Spanish experience. IZA J Labor Stud 1:1-29. doi:10.1186/2193-9012-1-4

Biavaschi C, Eichhorst W, Giulietti C, Kendzia MJ, Muravyev A, Pieters J, Rodriguez-Planas N, Schmidl R, Zimmermann KF (2012) Youth Unemployment and Vocational Training. IZA Discussion Paper No 6890. IZA, Bonn

Boeri T (2011) Institutional Reforms and Dualism in European Labor Markets. In: Card D, Ashenfelter O (eds) Handbook of Labor Economics: Part B, 4th edn. Elsevier, Amsterdam, pp 1173-1236

Boldrin M, Dolado JJ, Jimeno JF, Peracchi F (1999) The future of pensions in Europe. Econ Policy 14(29):287-320

Boone J, van Ours JC (2004) Effective Active Labor Market Policies. IZA Discussion Paper No 1335. IZA, Bonn

Chan S, Stevens AH (1999) Employment and retirement following a late-career job loss. Am Econ Rev 89:211-216. doi:10.1257/aer.89.2.211

Chan S, Stevens AH (2001) Job loss and employment patterns of older workers. J Labor Econ 19:484-521. doi:10.1086/319568

Commission E (2013) Youth employment: Commission welcomes Council agreement on youth guarantee. http:// europa.eu/rapid/press-release_MEMO-13-152_en.htm. Accessed on 27 November 2013

Council of the European Union (2013) Proposal for a council recommendation on establishing a youth guarantee No 6463/13. Brussels, 22 February 2013

Crepon B, Deniau N, Perez-Duarte S (2003) Wages, productivity and worker characteristics: A French perspective. INSEE

Daniel K, Heywood JS (2007) The determinants of hiring older workers. Labour Econ 14:35-51. doi:10.1016/j. labeco.2005.05.009

De Grip A, van Loo J (2002) The Economics of Skills Obsolescence: a Review. In: de Grip A, van Loo J, Mayhew K (eds) The Economics of Skills Obsolescence: Theoretical Innovations and Empirical Applications (Research in labor economics), vol 21. Elsevier, London, pp 1-26

De Jong P, Lindeboom M, van der Klaauw B (2011) Screening disability insurance applications. J Eur Econ Assoc 9:106-129. doi:10.1111/j.1542-4774.2010.01002.x

Dostie B (2011) Wages, productivity and aging. De Economist 159:139-158. doi:10.1007/s10645-011-9166-5

Dygalo NN, Abowd JM (2005) Estimating experience-productivity profiles from earnings over employment spells, Working Paper. University of Western Ontario, London CN

Eichhorst W, Hinte H, Rinne U (2013) Youth Unemployment in Europe: What to do about it? IZA Policy Paper No 65. IZA, Bonn 
Eurofound (2012) Employment Trends and Policies for Older Workers in the Recession. Publications Office of the European Union, Luxembourg, http://www.lo.org/public/libdoc/igo/2012/470631.pdf. Accessed 27 November 2013

European Commission (2008) The 2009 ageing report: underlying assumptions and projection methodologies. Eur Econ 7. doi:10.2765/51050

European Commission (2010) A New Impetus for European Cooperation in Vocational Education and Training to Support the Europe 2020 Strategy. Communication from the Commission to the European Parliament, the Council, the European Economic and Social Committee and the Committee of the Regions, Brussels, 9.6.2010, COM(2010) 296 final

European Commission (2011a) Youth employment measures 2010. European Employment Observatory Review. doi:10.2767/21405

European Commission (2011b) Youth on the move: A Europe 2020 initiative. http://ec.europa.eu/youthonthemove/ about/policy-actions/index_en.htm. Accessed 27 November 2013

European Commission (2012a) Preparatory Action "Youth Guarantee": Supporting Partnerships for Activation Measures Targeting Young People through Projects in the Context of Youth Guarantee Schemes at National, Regional or Local Level. Call for proposals No VP/2012/012, Employment, Social Affairs \& Inclusion, Brussels, August 2012

European Commission (2012b) The 2012 ageing report: Economic and budgetary projections for the $27 \mathrm{EU}$ member states (2010-2060). Eur Econ 2. doi:10.2765/19991

Federal Ministry of Labour and Social Affairs (2010) Training Pact: National Pact to Promote Training and Young Skilled Workers in Germany. http://www.bmas.de/EN/Our-Topics/Initial-and-Continuing-Training/training-pact.html. Accessed 27 November 2013

Fornero E (2012) Jobs for Europe. The Employment Policy Conference on 6-7 September 2012. European Commission, Brussels

Graf N, Hofer H, Winter-Ebmer R (2011) Labor supply effects of a subsidized old-age part-time scheme in Austria. J Labour Market Res 44:217-229. doi:10.1007/s12651-011-0072-8

Gruber J, Kubik JD (1997) Disability insurance rejection rates and the labour supply of older workers. J Public Econ 64:1-23. doi:10.1016/50047-2727(96)01590-3

Gruber J, Wise DA (2010) Social security programs and retirement around the world: The relationship to youth employment. The University of Chicago Press, Chicago IL and London

Hakola T, Määttänen N (2007) The effect of the pension reform on retirement age and income distribution - estimates from a dynamic programming model. Finnish Centre for Pensions, Helsinki

Hakola T, Uusitalo R (2005) Not so voluntary retirement decisions? Evidence from a pension reform. J Public Econ 89:2121-2136. doi:10.1016/j.jpubeco.2004.12.001

Hellerstein JK, Neumark D, Troske KR (1999) Wages, productivity and worker characteristics: Evidence from plant-level production function and wage equations. J Public Econ 17:409-446. doi:10.1086/209926

Hijzen A, Venn D (2011) The Role of Short-time Work Schemes during the 2008-09 Recession, OECD Social, Employment and Migration Working Paper No 115. doi:10.1787/5kgkd0bbwvxp-en

Hohbein A, Wieland C (2011) Ausbildungsgarantie zur Fachkräftesicherung: Die Initiative "Übergänge mit System" und was Deutschland von Österreich lernen kann. Berufsbildung 131:40-41

IImakunnas P, Maliranta M (2005) Technology, labor characteristics and wage-productivity gags. Oxf Bull Econ Stat 67:623-645

ILO (2010) Global Employment Trends for Youth: Special Issue on the Impact of the Global Economic Crisis on Youth. International Labour Office, Geneva

IMF (2012) Italy: Selected Issues. IMF Country Report No 12/168. IMF, Washington D.C

Johansson P, Jönsson L, Laun T (2012) Screening Stringency in the Disability Insurance Program. In: Laun L (ed) Studies on Social Insurance, Income Taxation and Labour Supply. Stockholm University, Stockholm, pp 83-114

Johnson P (1993) Ageing and European Economic Demography. In: Johnson P, Zimmermann KF (eds) Labour Markets in an Ageing Europe. Cambridge University Press, Cambridge

Jousten A, Lefèbvre M, Perelman S, Pestieau P (2010) The Effects of Early Retirement on Youth Unemployment: The Case of Belgium. In: Gruber J, Wise DA (eds) Social Security Programs and Retirement around the World: The Relationship to Youth Employment. University of Chicago Press, Chicago pp 47-76

Karlström A, Palme M, Svensson I (2008) The employment effect of stricter rules for eligibility for DI: Evidence form a natural experiment in Sweden. J Public Econ 92:2071-2082. doi: 10.1016/j.jpubeco.2008.04.014

Kluve J (2006) The Effectiveness of European Active Labor Market Policy. IZA Discussion Paper No 2018. IZA, Bonn

Koenig P, van Vuuren DJ (2010) Disability insurance and unemployment insurance as substitute pathways. Appl Econ 42:575-588. doi:10.1080/00036840701704436

Lexology (2012) The Reform of Italian Employment Law (92/2012): A Practical Overview. http://www.lexology.com/ library/detail.aspx?g=9ab9c7b6-ba7b-4b3e-8a75-cae72bdad0aa. Accessed 27 November 2013

Messe P-J, Bia M, Leombruni R (2010) Young-in Old-out: A New Evaluation. TEPP Working Paper N., 2010-14. working paper, reprint submitted to Labour Economics

Murphy KM, Welch F (1992) The structure of wages. Q J Econ 107(1):285-326

OECD (2013) Employment Outlook. OECD, Paris

Portugal P, Novo AA, Martins PS (2009) Increasing the Legal Retirement Age: The Impact on Wages. Worker Flows and Firm Performance, IZA DP No, 4187

Remery C, Henkens K, Schippers J, Ekamper P (2003) Managing an aging workforce and a tight labor market: Views held by Dutch employers. Popul Res Policy Rev 22:21-44. doi:10.1023/A:1023543307473

Rosen S (1975) Measuring the Obsolescence of Knowledge. In: Juster FT (ed) Education, Income and Human Behaviour. Carnegie Foundation and Columbia University Press, New York, pp 199-232

Saez E, Slemrod J, Giertz S (2012) The elasticity of taxable income with respect to marginal tax rates: A critical review. J Econ Lit 50:3-50. doi:10.1257/jel.50.1.3

Salem MB, Blanchet D, Bozio A, Roger M (2010) Labor Force Participation by the Elderly and Employment of the Young. The Case of France. In: Gruber J, Wise DA (eds) Social Security Programs and Retirement around the World: The Relationship to Youth Employment. University of Chicago Press, Chicago pp 119-146 
Skill (2009) Staying in education or training until you are 18. http://www.skill.org.uk/youth/page.aspx?c=309\&p=430. Accessed 27 November 2013

Staubli S (2011) The impact of stricter criteria for disability insurance on labor force participation. J Public Econ 95:1223-1235. doi:10.1016/j.jpubeco.2011.05.008

Staubli S, Zweimüller J (2011) Does raising the retirement age increase employment of older workers? IZA Discussion Paper No 5863. IZA, Bonn

Van Dalen HP, Henkens K (2002) Early-retirement reform: Can it and will it work? Ageing Soc 22:209-231. doi:10.1017/ S0144686X02008656

Wanger S (2009) Altersteilzeit: Beliebt, aber nicht zukunftsgerecht. IAB Kurzbericht 8. IAB, Nuremberg

Warr P (1998) Aging, Competence and Learning at Work. Aging of the Workforce Workshop on 23-24 March. Brussels

10.1186/2193-9012-3-19

Cite this article as: Eichhorst et al:: How to combine the entry of young people in the labour market with the retention of older workers? IZA Journal of European Labor Studies 2014, 3:19

Submit your manuscript to a SpringerOpen ${ }^{\circ}$ journal and benefit from:

- Convenient online submission

- Rigorous peer review

- Immediate publication on acceptance

- Open access: articles freely available online

- High visibility within the field

- Retaining the copyright to your article

Submit your next manuscript at $\boldsymbol{\nabla}$ springeropen.com 